УДК 622.271:338

В.І. Прокопенко /д.т.н./, А.Ю. Череп /к.т.н./, Д.П. Пілова / к.е.н./

НТУ «Дніпровська політехніка», м. Дніпро, Україна

\title{
ТЕХНОЛОГО-ЕКОНОМІЧНІ АСПЕКТИ ЕФЕКТИВНОСТІ ГІРНИЧО-ЗБАГАЧУВАЛЬНОГО ВИРОБНИЦТВА МАРГАНЦЕВОРУДНОЇ СИРОВИНИ
}

Vasyl Prokopenko/Dr. Sci. (Tech.)/, Andrii Cherep/Cand. Sci. (Tech.)/, Daria Pilova /Cand. Sci. (Econ.)/
National Technical University "Dnipro

Polytechnic", Dnipro, Ukraine

\section{TECHNOLOGICAL AND ECONOMICAL ASPECTS OF EFFECTIVENESS OF MINING AND PROCESSING PRODUCTION OF MANGANESE ORE}

\begin{abstract}
Мета - узагальнення вихідних даних та науково-прикладне визначення технологічних факторів, які обумовлюють конщептуальний підхід до поліпшення економічних результатів процесів видобування корисної копалини та ї̈ збагачення, а в підсумку ефективність виробничої діяльності гірничо-збагачувального підприємства.

Методика полягає в обтрунтуванні факторів технологічного й економічного підходів до оцінювання виробничих процесів видобування й збагачення марганцеворудної сировини, що визначають собівартість концентрату, втрати запасів рудної сировини та металу у відходах збагачення, а також обсяг розкривних порід, які треба розробити для виготовлення заданого обсягу кониентрату.
\end{abstract}

Результати. Визначена невідповідність технологічної схеми гірничих робіт на марганцевих кар'єрах ПГЗК вимогам виробництва конкурентного концентрату у разі зниженого попиту, $a$ також напрям ї̈ реконструкиії. Обгрунтований вплив якості рудо-потоку на економічні результати гірничо-збагачувального виробництва й визначено рачіональні умови усереднення якості рудної сировини різних кар'єрів. Розроблений науково-прикладний підхід до визначення раціонального обсягу розкривних порід, який забезпечує розкриття рудного пласта в обсязі, що дозволяє мінімізувати витрати кар 'єру на розкривні роботи.

Наукова новизна. Визначений принцип удосконалення технологічної схеми видобування горизонтального рудного пласта при зниженому попиті на продукиію. Узагальнений методичний підхід до оцінювання ефективності виробничої діяльності гірничо-збагачувального підприємства, ураховуючи собівартість концентрату, втрати запасів рудної сировини та металу у відходах збагачення, а також обсяг розкривних порід, щьо задовольняс ринковий попит на конщентрат. Встановлена певна непрямолінійна залежність між якістю марганщевої руди та ступенем вилучення металу в концентрат, яку слід оцінювати при формуванні рудо-потоку, що збагачується.

Практичне значущість. Очінена технологія гірничих робіт на кар'єрах ПГЗК за собівартістю концентрату, що відображає їх адаптачію до ринкових умов господарювання. Визначений статистичний взаємозв'язок між технолого-економічними умовами видобування рудної сировини та якістю рудо-потоку (за вмістом металу). Запропонований методичний підхід до усереднення марганцевої руди по двох групах кар'єрів, щэо забезпечує найбільший обсяг вилученого металу та мінімізує витрати підприємства на розкривні роботи.

Ключові слова: кар'єр, виробничі прочеси, марганцева руда, якість рудо-потоку, технологоекономічна ефективність, методичні засади, вилучення металу, собівартість концентрату.

DOI: 10.34185/0543-5749.2019-3-4-32-41

(C) Прокопенко В.І., Череп А.Ю., Пілова Д.П., 2019 г. 
Вступ. У проектах відкритої розробки родовищ певні обмеження на використання природних ресурсів зазвичай не розглядаються. Цей напрям може бути реалізований без зниження обсягів випуску й збільшення витрат, адже він передбачає раціональний розподіл цих обсягів з урахуванням технолого-економічних факторів, які орієнтують ведення виробничих процесів за умови обмеження природних ресурсів. На сьогодні наукові пошуки щодо еколого-економічних способів розкриття та систем розробки родовищ корисних копалин не відзначаються технологічною ефективністю. Розробка родовищ грунтується головним чином на традиційних добре апробованих технологіях гірничих робіт. Ці технології передбачають передусім видобування найбільшого обсягу корисної копалини. Хоча останнім часом вчені демонструють підвищену науково-прикладну зацікавленість в економіко-математичному обгрунтуванні технологічних рішень стосовно різних етапів відпрацювання родовища - від будівництва до ліквідації гірничого підприємства.

Розв'язання проблеми ефективності гірничо-збагачувального виробництва визначає не тільки раціональне використання природних ресурсів, але й суттєво впливає на економічні результати діяльності підприємства. Названі особливості визначають вимоги та обмежують вихідні умови виробництва, саме вони формують чинники впливу на технологічну ефективність виробництва металургійної сировини.

Огляд літератури. Розвиток технології гірничого підприємства 3 погляду на екологоекономічну оцінку виробничих процесів формується як узагальнена модель дій, спрямованих на підвищення обсягу прибутку підприємства, рівня вилучення запасів з надр, зниження витрат на видобування і збагачення руди, обсяг відходів і викидів шкідливих речовин тощо. Відзначимо наукові праці, пов'язані 3 розв'язанням названої вище проблеми.

Передусім, слід назвати результати досліджень Шапара А.Г. та Четверика М.С., які значною мірою розв'язують питання технологічного зниження впливу відкритих гірничих робіт на обсяги порушення природного середовища. У публікації [1] пропонована технологічна номограма оперативного планування обсягів видобувних та розкривних робіт в кар'єрі за умови мінімізації площі земельного відводу. При цьому виключається зовнішнє відвалоутворення, суттєво скорочуються обсяги рекуль- тиваційних робіт. У статті [2] викладені дослідження з розв'язання актуальної проблеми охорони природних ресурсів. Розроблена технологія попереднього збагачення руди в кар'єрі, що дозволяє зменшити іiі втрати та розубоження, вилучити позабалансові запаси й підвищити потужність гірничого підприємства.

До значного зниження впливу на природні ресурси приводять розглянуті Романенком О.В. [3] технологічні схеми відпрацювання крутоспадаючих родовищ із внутрішнім відвалоутворенням. Впровадження в практику таких схем уможливлює зменшення сумарних витрат на розробку родовища на $7,6-25,1 \%$. У науковій праці [4] пропонована структура двовимірної гіпотетичної моделі геологічного блоку для планування параметрів гірничих робіт, що дозволяє скласти систему моделювання робочої зони кар'єру, а в підсумку визначити ймовірні строки та витрати на його закриття. Стосовно цієї проблеми показники життєзабезпечення оцінюються й порівнюються за критеріями стабільності місцевих жителів та керівних осіб, що ухвалюють рішення [5]. Тому критерії слід розглядати для запобігання необгрунтованих дій 3 погляду сприяння сталому розвитку на місцевому рівні.

Запропонована реальна модель опціону для оцінки вартості видобування рудної сировини відкритим способом в умовах невизначеності іiі ринкової ціни [6]. Модель дозволяє максимізувати чисту приведену вартість видобувного комплексу, виходячи 3 послідовності й швидкості вилучення рудних запасів.

Приведена глобальна оптимізація гірничодобувних комплексів, спрямована на створення графіку гірничих робіт для різних кар'єрів і технологічних схем за умови максимізації економічної цінності підприємства в цілому [7]. Викладений методичний підхід до планування гірничих робіт на основі більш точних прогнозів відхилень параметрів виробничих процесів у кар'єрі від первісних планів, що приводить до кращого прогнозування 3 мінімальними втратами [8].

Для проектування кар'єру важливе значення мають кількісні оцінки екологічних витрат на видобування корисної копалини. В цьому аспекті представлений метод планування графіку гірничих робіт з безпосереднім урахуванням прямих екологічних витрат [9].

Виділення невирішених частин проблеми. В розглянутих публікаціях недостатньо розроблені методичні засади економічного обгру- 
нтування чинників, що впливають на технологічну ефективність комплексів гірничих робіт у кар'єрах. Через слабку адаптацію до кон'юнктури ринку, невідповідність технологічних схем гірничих робіт економічним вимогам експлуатації родовища деякі гірничозбагачувальні комбінати (ГЗК) суттєво знизили обсяги видобутку. Сьогодні впровадження нових більш гнучких технологій, що відповідають вимогам ринку металургійної сировини, є однією 3 головних складових проблеми успішної роботи гірничих підприємств.

Загалом технологічна ефективність розробки горизонтальних родовищ, на думку авторів, грунтується на рішеннях, що будуть відповідати таким умовам:

1) видобувні роботи на кар'єрі здійснюють відокремленим уступом, для транспортування руди використовують навантажувачі або автосамоскиди;

2) технологічна схема гірничих робіт забезпечує поперечне переміщення розкривних порід у відвал (без використання конвеєрної доставки);

3) комплекс устаткування забезпечує видобування рудної сировини в обсязі, що відповідає ринковому попиту.

Розв'язання питань, пов'язаних з визначенням факторів впливу на обсяги використаних кар'єром природних ресурсів, є важливим для розробки загальної концепції вибору методів ресурсозбереження й, за браком достатньої інформації в наукових публікаціях за цим напрямом, потребує подальшого методичного обгрунтування.

Мета статті. Протиріччя технологічних та економічних інтересів підприємств гірничодобувної галузі обумовлені об'єктивними чинниками - обмеженістю природних ресурсів та недосконалістю сьогоднішніх виробничих процесів видобування й переробки корисної копалини. Тому мета статmі полягає в узагальненні вихідних даних та методичному визначенні технологічних факторів, які формують концептуальний підхід до підвищення ефективності гірничодобувного процесу в кар'єрі, а також наступного процесу збагачення рудної сировини, що в підсумку впливає на ефективність гірничо-збагачувального виробництва. Дослідження виконані стосовно кар'єрів і збагачувальних фабрик Покровського ГЗК (ПГЗК).

Основні результати. Раціональною для марганцевих кар'єрів ПГЗК, що відпрацьовують горизонтальні родовища, є технологічна схема розробки розкривних порід трьома уступами за безтранспортною (надрудний уступ) і транспортно-відвальною системами (передовий і проміжний уступи). Передовий (верхній) уступ розробляють роторним комплексом (SRs$2400+\mathrm{VR})$, розкривні породи переміщують та складують у відвал конвеєром КЛ-2000 та відвалоутворювачем ОШР. Для відпрацювання проміжного (основного) уступу застосовують роторний екскаватор ЭРШР-5250, перевантажувач ПГ та відвалоутворювач ОШР. Нижній (надрудний) уступ переміщують у відвал крокуючими екскаваторами типу ЭШ-15/90 або ЭШ-20/90.

Представлена технологічна схема відроблення розкривних порід достатньо відповідає сучасним вимогам експлуатації горизонтального родовища, проте має недоліки в плані забезпечення конкурентних переваг виготовленого концентрату з таких причин:

1) висока вартість транспортування розкривних порід;

2) значні простої великої кількості технологічного устаткування;

3) підвищені втрати обсягів та якості видобутої рудної сировини.

Названі фактори відображають технологічну ефективність видобутку й переробки (збагачення) марганцевої руди, а, в підсумку, обумовлюють конкурентоспроможність металургійної сировини згідно з ринковим попитом. Розглянемо детальніше ці фактори, що визначить шляхи надання продукції конкурентних переваг.

Витрати на процеси видобутку і збагачення руди оцінюються собівартістю $B_{\kappa t i}$ виробництва концентрату. Ця собівартість включає витрати $B_{\text {dit }}$ на видобування марганцевої руди в кар'єрі та ii транспортування на збагачувальну фабрику. Стосовно умов видобування руди на $i$-му кар'єрі в в $t$-му році з початку етапу його роботи, що розглядається, маємо:

$$
\begin{aligned}
& B_{k i t}\left(M n_{p i}, M n_{k i}\right)= \\
& =\left[\left(B_{\partial i t}+B_{n i t}\right) \frac{M n_{k}}{M n_{p i} \varepsilon}+B_{3 i t}\right] \cdot \frac{O_{p i} M n_{p i}}{M n_{k} \varepsilon}+ \\
& +I B_{i t}+O C_{i t}, \text { грн./рік, }
\end{aligned}
$$

де $B_{k i t}\left(M n_{p i}, M n_{k i}\right)$ - витрати на виробництво концентрату залежно від вмісту марганцю в концентраті $M n_{k i}$ та в рудній сировині $M n_{p i}, \%$, на $i$-му кар'єрі; $B_{\text {dit }}, B_{n i t}, B_{3 i t}-$ витрати на видобування безпосередньо марганцевої руди, розкривні роботи та збагачення руди, відповідно; 


$$
\begin{aligned}
& B_{\partial i t}=\left(C_{\text {ді }}\left(1+t K_{\text {ді }}\right)\left(1+K_{ч}\right)^{t-1},\right. \text { грн./т; } \\
& B_{n i t}=\sum_{j=1}^{n} C_{n i j} \frac{H_{\mathrm{yit}}}{m_{\mathrm{pit}}}\left(1+t K_{n i}\right) \times \\
& \left.\times\left(1+K_{ч}\right)^{t-1}\right), \text { грн./т; } \\
& B_{3 i t}=\sum C_{3 \mathrm{i}}\left(1+t K_{3}\right) \times \\
& \times\left(1+K_{ч}\right)^{t-1}, \text { грн./т; }
\end{aligned}
$$

$C_{\partial i}-$ собівартість безпосередньо видобування 1 т руди на $i$-му кар'єрі, грн.; $K_{\partial i}, K_{n i}-$ підвищення витрат унаслідок зношування технологічного устаткування та погіршення умов його експлуатації, відповідно, на видобування руди та розроблення розкривної породи, частка од.; $K_{u}-$ підвищення витрат на гірничотранспортні роботи під впливом фактору часу видобування руди, часка од.; $C_{n j}$ - собівартість розроблення $1 \mathrm{~m}^{3}$ розкривних порід на $j$-му уступі $i$-го кар'єру, грн./м;; $H_{y j t}, m_{p i t}-$ відповідно, висота $j$-го уступу та потужність рудного пласту на $i$ му кар'єрі, м; $n$ - загальна кількість розкривних уступів на кар'єрі; $C_{3 i}$ - собівартість збагачення руди $3 i$-го кар'єру для виготовлення 1 т концентрату, грн./т; $\varepsilon_{i}-$ коефіцієнт вилучення $M n_{p i}$ в концентрат 3 руді $i$-го кар'єру, частка од.; $I B_{i t}, O C_{i t}-$ обсяг інвестиційних вкладень, спрямованих, відповідно, на розвиток техніки й технології гірничо-збагачувального виробництва та на охорону середовища, грн./рік; $O_{p i t}-$ плановий обсяг видобутку марганцевої руди на $i$-му кар'єрі в t-му році, т/рік.

Оцінимо технологію видобування горизон- тального пласта марганцевої руди на кар'єрах ПГЗК упродовж 10 років. Виходячи з ринкового попиту на концентрат - 12500 т на місяць визначена продуктивність кар'єру по руді600 тис. т на рік. Витрати $C_{3 i}$ на безпосередньо збагачення руди 3 будь якого кар'єру для виготовлення 1 т концентрату прийнято рівними 5,57 грн., обсяг інвестицій $I B_{i t}$ на розвиток технічних засобів - 3300 тис. грн./рік.

На підставі розрахунків за формулою (1) 3 початку періоду, що розглядається, найменші майже однакові ( 3 різницею $4 \%$ ) витрати на гірничо-збагачувальне виробництво досягаються при використанні рудної сировини, видобутої на Шевченківському та Північному кар'єрах (табл. 1). Це відбувається завдяки більш працездатним комплексам устаткування та сприятливішим гірничо-геологічним умовам відпрацювання рудного пласта на цих кар'єрах. Складні умови видобувних робіт, а також експлуатація сильно зношеного технологічного устаткування спричиняють на кар'єрі Чкаловський-1 найбільші витрати на виробництво концентрату (подорожчання порівняно 3 середнім рівнем витрат $25 \%$ ). Крім зазначеного вище, це можна пояснити невідповідністю потужного на кар'єрі устаткування, що потребує значних витрат на його обслуговування, фактичному попиту на рудну сировину, що сильно скоротився останнім часом. Отже, впроваджені на зазначених вище кар'єрах комплекси устаткування, які краще адаптовані до технологічних схем гірничодобувних робіт, за витратами на виробництво концентрату є більш вигідними, ніж на Чкаловському-1 та Чкаловському-2 кар'єрах.

Таблиця 1. Основні складові витрат на гірничо-збагачувальне виробництво

\begin{tabular}{|c|c|c|c|c|c|}
\hline \multirow{2}{*}{ Кар'єр } & \multicolumn{2}{|c|}{ На 1 т рудної сировини, грн. } & \multicolumn{2}{c|}{ На 1 т концентрату, грн. } \\
\cline { 2 - 6 } & $\begin{array}{c}\text { розробка } \\
\text { розкривних } \\
\text { порід }\end{array}$ & $\begin{array}{c}\text { видобуток ру- } \\
\text { ди }\end{array}$ & $\begin{array}{c}\text { доставка } \\
\text { руди }\end{array}$ & $\begin{array}{c}\text { охорона } \\
\text { довкілля }\end{array}$ & усього \\
\hline Шевченківський & 3,55 & 26,46 & 3,55 & 14,34 & 129,17 \\
\hline Північний & 6,35 & 39,31 & 6,35 & 18,04 & 134,47 \\
\hline Чкаловський-2 & 11,30 & 34,64 & 11,3 & 21,31 & 142,39 \\
\hline Чкаловський-1 & 9,60 & 35,85 & 9,6 & 21,03 & 167,38 \\
\hline $\begin{array}{c}\text { Чкаловський-1 (80 \%)+ } \\
\text { Шевченківський (20\%) }\end{array}$ & 8,39 & 33,97 & 8,39 & 19,69 & 159,84 \\
\hline $\begin{array}{l}\text { Чкаловський-1 (60 \%)+ } \\
\text { Шевченківський (40 \%) }\end{array}$ & 7,18 & 32,09 & 7,18 & 18,35 & 152,1 \\
\hline
\end{tabular}

Для повнішого використання наявних запасів марганцеворудної сировини в родовищі з кар'єрів на збагачення спрямовується рудо-потік усередненої якості (за вмістом $M n_{p}$ ), для чого багата й 
бідна руда 3 різних кар'єрів змішується. Крім того, це дозволяє контролювати витрати на виробництво концентрату шляхом усереднення собівартості видобутої сировини. Залежно від співвідношення показників якості руди та іiї собівартості на кар'єрах, які об'єднуються одним рудо- потоком, витрати на виробництво концентрату або знижуються або підвищуються. Так, примішуючи 20-40\% бідної, проте дешевої руди Шевченківського кар'єру до дорогої руди 3 кар'єру Чкаловський-1 витрати на концентрат можуть бути знижені відповідно на 5 - 10 \% (рис. 1).

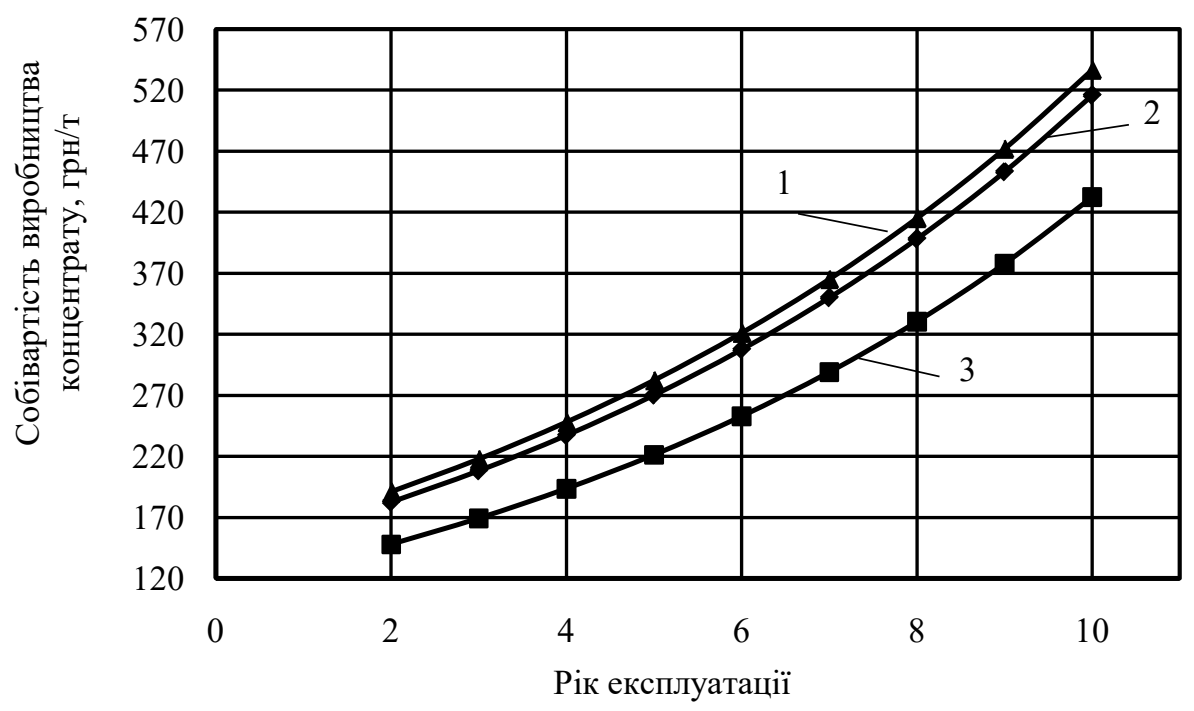

Рис. 1. Собівартість виробництва концентрату при використанні рудної сировини різних кар'єрів: 1 - Чкаловський-1, 2 - Чкаловський-1 (60 \%) і Шевченківський (40 \%), 3 - Шевченківський

При обгрунтуванні доцільного рівня усереднення якості руди за критерієм собівартості виробленого концентрату треба ураховувати, що вміст металу $M n_{p}$ в руді впливає на коефіцієнт $\varepsilon$ вилучення цього металу в концентрат, а значить, на втрати експлуатаційних запасів рудної сировини родовища (рис. 2). За статистичними даними збагачувальних фабрик ПГЗК між коефіцієнтом $\varepsilon$ та вмістом металу $M n_{p}$ існує статистична залежність:

$$
\begin{aligned}
\varepsilon= & -0,0168 \cdot M n_{p}{ }^{2}+2,4025 \cdot M n_{p}+ \\
& +15,583, \% ; \quad R^{2}=0,941 .
\end{aligned}
$$

На підставі залежності (5) підвищення вмісту марганцю в руді при незначному вмісті $(21-25 \%)$ не призводить до суттєвого підвищення рівня вилучення металу в концентрат (від $61 \%$ до $64 \%$ ), у той же час при високому вмісті (28 - $32 \%)$ підвищення вмісту марганцю дозволяє значно підвищити рівень цього вилучення (від $68 \%$ до $76 \%$ ), завдяки чому досягаються найменші втрати металу. Значить, найменші втрати металу $M n_{p}$ будуть відбуватися при розподілі видобутку руди та ії збагаченні окремими рудо-потоками. Усереднення руди по групах кар'єрів за названим критерієм ефективності слід здійснювати так, щоб в одній групі складався низький, а в другий - високий вміст марганцю в рудній сировині.

У відходах збагачення, що спрямовуються у хвостосховище, втрачається певний обсяг металу (марганцю). Встановимо обсяг металу, вилученого з рудної сировини в процесі іiї збагачення, адже він характеризує рівень втрат рудних запасів в родовищі. Втрати металу у відходах збагачення рудо-потоку $i$-го кар'єру можуть бути визначені за вираженням:

$$
M e_{i}=O_{p i} M n_{p i}\left(1-\varepsilon_{i}\right), \mathrm{T} / \text { рік. }
$$

Використовуючи вираження (6) стосовно показників видобутку руди та виробництва концентрату на Покровському ГЗК (табл. 2). Причому прийнято, що той чи інший кар'єр має забезпечувати виробництво заданого обсягу концентрату (12500 т на місяць) згідно 3 попитом ринку на концентрат.

Сьогодні збагачувальні фабрики виробляють концентрат з рудної сировини, яку поставляє періодично той чи інший кар'єр. Якщо концентрат виробляється з багатої руди, то обсяг її видобутку знижується, а значить, знижується обсяг розкривних порід, які треба було б видалити 3 кар'єрів при видобуванні руди середньої якості. У той же час, при виготовленні заданого обсягу концент- 
рату 3 бідної руди потрібно буде видобувати іiі більший обсяг, що призведе до підвищення обсягу розкривних порід. Встановимо обсяг цих порід, який може бути скорочений, якщо обсяг річного видобутку буде усереднюватись за якістю руди, що збагачується, шляхом змішування декількох кар'єрних потоків.

За результатами розрахунку авторів, нижча якість марганцевої руди $(21,85 \% \mathrm{Mn})$ призводить до нижчого коефіцієнту вилучення мета- лу $(0,601)$ та найбільших обсягів збагачення руди (41,36 тис. т/міс.), хвостів збагачення (28,86 тис. т/міс.) та розробки розкривних порід $\left(570,8\right.$ тис. м $^{3} /$ міс). Підвищення якості рудної сировини дозволяе поліпшити показники виробництва концентрату за рахунок меншого обсягу розкривних порід. Так, Змішування рудної сировини у рівних обсягах для випуску 600 тис.т концентрату показує можливість їх скорочення від $4,71 \%$ до $10,05 \%$.

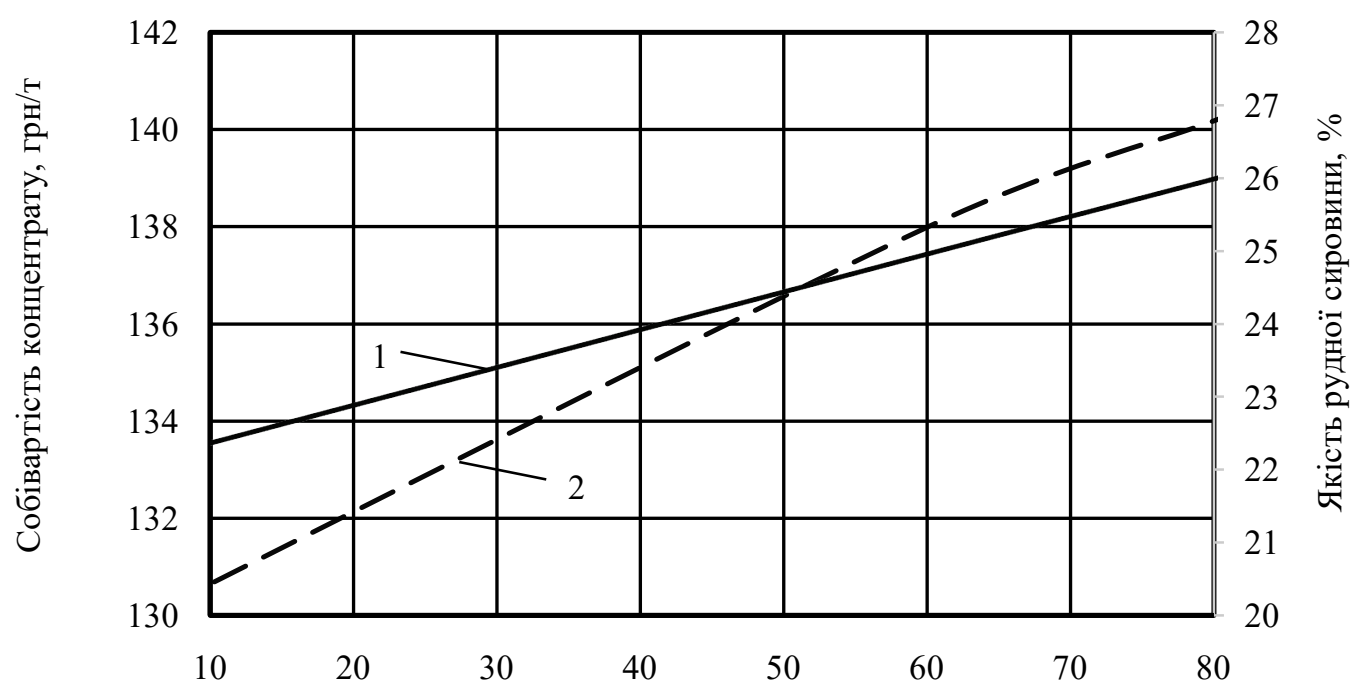

Частка багатої рудної сировини в загальному обсязі рудної сировини, використаної для виробництва марганцевого концентрату, \%

Рис. 2. Графіки, що демонструють вплив якості рудної сировини (1) на собівартість виробництва концентрату (2)

Таблиця 2. Показники гірничо-збагачувального процесу на Покровському ГЗК

\begin{tabular}{|c|c|c|c|c|}
\hline Кар'єр & $\begin{array}{c}\text { Видобуток руди, } \\
\text { тис. т/міс. }\end{array}$ & $\begin{array}{c}\text { Вміст марганцю } \\
\text { в руді,\% }\end{array}$ & $\begin{array}{c}\text { Коефіцієнт } \\
\text { вилучення металу }\end{array}$ & $\begin{array}{c}\text { Втрати металу, тис. } \\
\text { т/міс. }\end{array}$ \\
\hline Чкаловський-1 & 36,31 & 23,69 & 0,63 & 3,17 \\
\hline Чкаловський-2 & 29,42 & 27,03 & 0,68 & 2,53 \\
\hline Північний & 33,36 & 24,99 & 0,65 & 2,91 \\
\hline Шевченківський & 41,36 & 21,85 & 0,60 & 3,60 \\
\hline
\end{tabular}

Якщо треба виробити згідно з попитом обсяг концентрату $O_{k n}$, то для цього слід видобути обсяг руди $O_{p n}$. При поділі всього обсягу руди, що видобувають декілька кар'єрів, кожен з них має забезпечити рудну сировину в обсязі $O_{p i}$. Виходячи 3 цього обсягу руди, $i$-й кар'єр має розробити відповідний обсяг розкривних порід $V_{n i}$. У такому разі буде виконуватися умова:

$$
V_{n i}=O_{p i} K_{p i}=O_{\kappa i} \beta_{i} K_{p i}, \mathrm{~m}^{3} / \text { міс. (рік), }
$$

де $K_{p i}$ - коефіцієнт розкриття при видобуванні руди на $i$-му кар'єрі, $\mathrm{m}^{3} / \mathrm{T} ; \beta_{i}$ - витрата руди $i$-го кар'єру на 1 т концентрату, т.

Вираження (3) дозволяе планувати коефіцієнт розкриття рудного пласта згідно 3 якістю рудної сировини. Як витікає з вираження, обсяг розкривних порід можна регулювати зміною виходу концентрату $\beta_{i}$ з сирої руди $i$-го кар'єру за рахунок їі якості - від бідної руди до багатої відносно усередненої. Зниження чи перевищення сумарного обсягу розкриву $\Delta V_{n}$ який треба видалити 3 кар'єру для видобування заданого обсягу руди $O_{p}$ i виробництва концентрату $O_{k}$, встановлюється виходячи 3 суми обсягів розк- 
ривних порід, що забезпечують видобування обсягів усіх кар'єрних рудо-потоків.

Розглянуто ефективність запропонованого рішення щодо збагачення заданого обсягу руди за окремими рудо-потоками, виходячи з обсягів розкривних порід та відходів (рис 3). Досліджено два рудо-потоки, що за вмістом марганцю в руді суттєво відрізняються між собою (бідного $20 \%$ та багатого - $32 \%$, у середньому - $26 \%$ ).
Якщо вміст підвищується 3 20\% до 26\%, то необхідний обсяг розкриву зменшується на 185 тис. м³/міс., а при зниженні вмісту з $32 \%$ до $26 \%$ - збільшується на 140 тис. м $^{3} /$ міс. (рис. 3,a). Аналогічно змінюються місячні обсяги відходів збагачення: 19 і 10 тис. т (рис. 3, б). Ці результати розрахунку свідчать про доцільність роздільного збагачення багатого та бідного рудо-потоків.
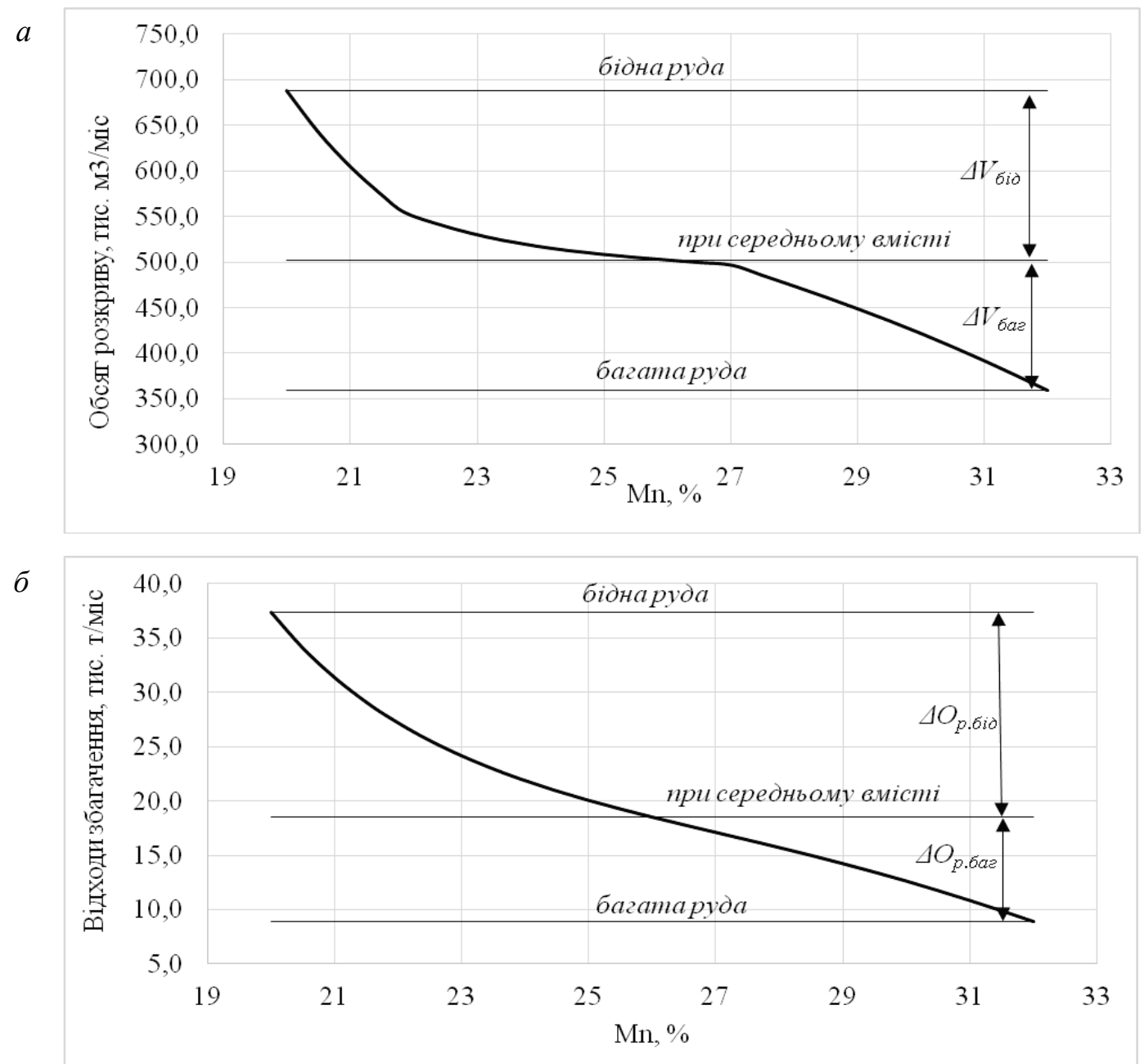

Рис. 3. Графіки зміни обсягів розкривних порід (a) та відходів збагачення (б) в залежності від вмісту марганцю в кар'єрному рудо-потоці

Висновки. 1. Впроваджена на марганцевих кар'єрах ПГЗК технологічна схема видобування рудного пласта базується на розробці трьох високих розкривних уступів (висотою біля 20 чи 30 м) потужними гірничо- транспортними комплексами (продуктивністю понад 10 млн м ${ }^{3}$ на рік). За своєю конструкцією така схема не може перевлаштуватися на видобування рудної сировини для виробництва конкурентного концентрату в малому обсязі у разі зниженого попиту.

2. Обгрунтовано, що технологія видобування горизонтального рудного пласта відкритим спо- собом в ринкових умовах господарювання гірничого підприємства має базуватися на застосуванні багатьох одиниць кар'єрного устаткування 3 невеликими робочими розмірами, що розміщені на значному по довжині фронті видобувних, розкривних та відвальних робіт (за принципом розподілу робочих забоїв в глибоких кар'єрах).

3. Обгрунтовано, що технологічні й економічні умови видобування й перероблення рудної сировини у цілому характеризуються якістю рудо-потоку (за вмістом металу), яка утворюється цими умовами. Узагальнений методичний підхід 
до оцінювання ефективності діяльності гірничозбагачувального підприємства, ураховуючи собівартість концентрату, втрати запасів рудної сировини та металу у відходах збагачення, а також обсяг розкривних порід, які треба видалити 3 кар'єру для задоволення ринкового попиту на концентрат. Якість рудо-потоку впливає на величину названих критеріїв оцінки й тим самим визначає раціональні умови формування рудопотоку.

4. Вплив названих у п. 3 критеріїв оцінки в цілому відображає ступень вилучення металу 3 рудної сировини в концентрат. За даними ПГЗК, між цим ступенем та якістю марганцевої руди існує певна непрямолінійна залежність, згідно 3 якою підвищення вмісту марганцю в руді при незначному вмісті не приводить до суттєвого підвищення ступеню вилучення металу, а при високому вмісті його підвищення дозволяе значно підвищити ступень вилучення. Звідси витікає, що якість марганцевої руди слід розподіляти й усереднювати по двох групах кар'єрів так, щоб в одній групі був отриманий низький, а в другий - високий вміст марганцю в рудній сировині. Це забезпечує найбільший у сумі для двох рудо-потоків обсяг вилученого металу.

5. Розроблено науково-прикладний підхід до визначення раціонального обсягу розкривних порід, що забезпечує розкриття рудного пласта в обсязі, обумовленому раціональним ступенем вилучення металу з рудної сировини при іiї збагаченні декількома рудо-потоками. Такий підхід дозволяє мінімізувати витрати кар'єру на розкривні роботи. Якщо марганцеву руду збагачувати роздільними (бідною і багатою) потоками, то необхідний обсяг розкриву стосовно умов ПГЗК зменшується на 45 тис. ${ }^{3} /$ міс. (10\%).

6. Ринкова економіка суттєво впливає на результати виробничої діяльності гірничозбагачувальних підприємств, передусім, на обсяг реалізації виробленої продукції. В наукових публікаціях цьому чиннику у взаємозв'язку 3 технологією процесів видобування та перероблення корисної копалини приділяється недостатньо уваги. Безумовно, цей чинник потребує більш детальних обгрунтувань, на що варто спрямувати подальші дослідження.

\section{Бібліографічний список}

1. Шапарь А.Г., Якубенко Л.В. (2012) Разработка эколого-ресурсосберегающей технологии освоения крутопадащих месторождений. Еколологія і природокористування, (15), 96-106.

2. Четверик М.С., Бабий Е.В., Бубнова Е.А., Терещенко В.В. (2013) Основные направления рационального природопользования при открытой добыче полезных ископаемых. Гірничий вісник, 1(96), 58-62.

3. Романенко О.В. (2005). Обгрунтування раціональних областей застосування способів формування внутрішнього відвалу по економічній ефективності. Екологія $i$ природокористування, (8), 109-112.

4. Morteza Paricheh, Morteza Osanloo. (2017). A simulation-based framework for estimating probable open-pit mine closure time and cost. Journal of Cleaner Production, (167), 337-345.

5. Evren Deniz Yaylac1, H. Şebnem Düzgün. (2017). Evaluating the mine plan alternatives with respect to bottom-up and top-down sustainability criteria. Journal of Cleaner Production. (167), 837-849.

6. Matías Siña, Juan Ignacio Guzmán. (2018). Real option valuation of open pit mines with two processing methods. Journal of Commodity Markets. URL: https://www.sciencedirect.com/science/article/ pii/S2405851317302167

7. Ryan C. Goodfellow, Roussos Dimitrakopoulos. (2016). Global optimization of open pit mining complexes with uncertainty. Applied Soft Computing, (40), 292-304.

8. Shiv Prakash Upadhyay, Hooman AskariNasab. (2018). Simulation and optimization approach for uncertainty-based short-term planning in open pit mines. International Journal of Mining Science and Technology, (28 (2)), 153-166.

9. Xiao-chuan XU, Xiao-wei GU, Qing WANG, Jian-ping LIU, Jun WANG. (2014). Ultimate pit optimization with ecological cost for open pit metal mines. Transactions of Nonferrous Metals Society of China, (24 (5)), 1531-1537.

\section{References}

1. Shapar, A.G., \& Yakubenko, L.V. (2012) Razrabotka ekologo-resursosberegayushej tehnologii osvoeniya krutopadashih mestorozhdenij. Ekololohiia i pryrodokorystuvannia, (15), 96-106.

2. Chetverik, M.S., Babij, E.V., Bubnova, E.A., \& Tereshenko, V.V. (2013) Osnovnye napravleniya racionalnogo prirodopolzovaniya pri otkrytoj dobyche poleznyh iskopaemyh. Hirnychyi visnyk, 1(96), 58-62.

3. Romanenko, O.V. (2005). Obgruntuvannia ratsionalnykh oblastei zastosuvannia sposobiv formuvannia vnutrishnoho vidvalu po ekonomichnii efektyvnosti. Ekolohiia i pryrodokorystuvannia, (8), 109-112.

4. Morteza, Paricheh, \& Morteza, Osanloo. (2017). A simulation-based framework for estimating probable open-pit mine closure time and cost. Journal of Cleaner Production, (167), 337-345. 
5. Yaylacı, Evren Deniz, \& Düzgün, H. Şebnem. (2017). Evaluating the mine plan alternatives with respect to bottom-up and top-down sustainability criteria. Journal of Cleaner Production. (167), 837-849.

6. Siña, Matías, \& Guzmán, Juan Ignacio. (2018). Real option valuation of open pit mines with two processing methods. Journal of Commodity Markets. Retrieved from https://www.sciencedirect. com/science/article/pii/S2405851317302167

7. Goodfellow, Ryan C., \& Dimitrakopoulos, Roussos. (2016). Global optimization of open pit mining complexes with uncertainty. Applied Soft Computing, (40), 292-304.

8. Upadhyay, Shiv Prakash, \& Askari-Nasab. Hooman. (2018). Simulation and optimization approach for uncertainty-based short-term planning in open pit mines. International Journal of Mining Science and Technology, (28 (2)), 153-166.

9. Xiao-chuan, XU, Xiao-wei, GU, Qing, Wang, Jian-ping, LIU, Jun, Wang. (2014). Ultimate pit optimization with ecological cost for open pit metal mines. Transactions of Nonferrous Metals Society of China, (24 (5)), 1531-1537.

Цель - обобщение исходных данных и научно-прикладное определение технологических факторов, обуславливающих концептуальный подход к улучшению экономических результатов процессов добычи полезного ископаемого и его обогащения $u$, в результате повымение эффективности производственной деятельности горно-обогатительного предприятия.

Методика заключается в обосновании факторов технологического и экономического подходов оиенки производственных проиессов добычи и обогащения марганиеворудного сырья, определении себестоимости концентрата, потери запасов рудного сырья и металла в отходах обогащения, а также объема вскрышных пород, которые нужно разработать для изготовления заданного объема концентрата.

Результаты. Определено несоответствие технологической схемы горных работ на марганцевых карьерах ПГОКа требованиям производства конкурентного концентрата при пониженном спросе, а также направление ее реконструкции. Обосновано влияние качества рудо-потока на экономические результаты горно-обогатительного производства и определены рациональные условия усреднения качества рудного сырья различных карьеров. Разработан научно-прикладной подход к определению рачионального объема вскрышных пород, который обеспечивает вскрытие рудного пласта в объеме, позволяющем минимизировать расходы карьера на вскрышные работы.

Научная новизна. Определен принции совершенствования технологической схемы добычи горизонтального рудного пласта при пониженном спросе на продукцию. Обоснован методический подход оценки эффективности производственной деятельности горно-обогатительного предприятия, учитывающий себестоимость кониентрата, потери запасов рудного сырья и металла в отходах обогащения, а также объем вскрышных пород, который удовлетворяет рыночный спрос на концентрат. Установлена непрямолинейная зависимость между качеством марганцевой руды и степенью извлечения металла в концентрат. Данную зависимость следует оченивать при формировании обогащаемого рудо-потока.

Практическая значимость. Оченена технология горных работ на карьерах ПГОКа по себестоимости кониентрата, которая отражает их адаптацию к рыночным условиям хозяйствования. Определена статистическая взаимосвязь между технолого-экономическими условиями добычи рудного сырья и качеством рудо-потока (по содержанию металла). Предложен методический подход к усреднению марганцевой руды по двум группам карьеров, обеспечивающий наибольший объем изъятого металла и минимизируюший затраты предприятия на вскрышные работы.

Ключевые слова: карьер, производственные прочессы, марганцевая руда, качество рудо-потока, технолого-экономическая эффективность, методические основы, извлечение металла, себестоимость кониентрата.

The purpose is generalizing of output data and scientific and applied determining of technological factors that condition on the conceptual approach to improving the economic results of mining and processing of minerals and, as the result the efficiency of the production activities of a mining and processing enterprise.

The methodology is the substantiation of the factors of technological and economic approaches to the evaluation of production processes of mining and processing of manganese ore raw materials that determine a cost of a concentrate, losses of reserves of ore raw materials and metal in the waste of processing, as well as a volume of overburden, that should be developed for the production of a adjusted volume of concentrate.

Findings. The discrepancy of the technological scheme of mining operations on manganese open pits of the Pokrovsky ore mining and 
processing enterprise with the requirements for the production of competitive concentrate in the event of reduced demand, as well as the direction of its reconstruction, is determined. The influence of the quality of the ore stream on the economic results of the mining and processing production is substantiated and rational conditions for averaging of a quality of ore raw materials of different open pits are determined. Scientific and applied approach for determining of the rational volume of overburden, which provides an overburden of ore stream in a volume that allows minimizing an open pit's costs for overburden works, is developed.

Originality. The approach of improving of the technological scheme of mining of horizontal ore stream under the condition of reduced demand for products is determined. Methodical approach to the evaluation of the efficiency of mining activity of mining and processing enterprise is generalized taking into account concentrate cost, losses of reserves of ore raw materials and metal in the waste of processing, as well as the volume of overburden, which meets market demand for concentrate. The certain indirect correlation between a quality of manganese ore and a degree of metal extraction into a concentrate, which should be evaluated while processed ore-stream is forming, is determined.

Practical value. The technology of mining operations at the open pits of the Pokrovsky ore mining and processing enterprise according to concentrate cost that reflects their adaptation to market conditions is estimated. Statistical tie between technological and economic conditions for mining of ore raw materials and the quality of the ore stream (by the content of metal) is determined. The methodical approach is proposed for averaging of manganese ore in two groups of open pits, which provides the largest amount of extracted metal and minimizes the cost of the enterprise for overburden works.

Key words: open pit, production processes, manganese ore, quality of ore stream, technological and economic efficiency, methodical bases, metal extraction, concentrate cost.

Рукопис надійшов 31.07.2019. 